\title{
Analisis Kinerja Bagian Pengaduan Masyarakat Sekretariat Jenderal DPR RI
}

\author{
TULUS SANTOSO, ${ }^{1}$ TEGUH KURNIAWAN ${ }^{2}$ \\ 1,2) Program Studi Ilmu Administrasi, FISIP UI \\ email: ${ }^{1}$ tulussantoso87@gmail.com, ${ }^{2}$ teguh.kurniawan@ui.ac.id
}

\begin{abstract}
This study discusses about the performance of the Public Complaints Section, Secretariat General of the House of Representatives in managing the delivery process of public aspirations and complaints. To deepen the analysis, this research incorporates the concepts of organization, bureaucracy, and performance. This study applies a qualitative approach with descriptive type of writing. This study collects data through literature studies, interviews, and field observations. This study reveals that the Public Complaints Section has problems in terms of quantity and quality of human resource analysts. Public Complaints Section is neither effectively nor efficiently able to manage complaints and aspirations of the community. This makes the performance of Public Complaints Section underperformed. Finally, this study recommends that the General Secretariat of Parliament has to optimize the quantity and quality of human resources in the Public Complaints Section. Furthermore, members of the House of Representatives are expected to involve in empowering the section.
\end{abstract}

Keywords: public complaints, performance, organization, bureaucracy

\begin{abstract}
Abstrak. Penelitian ini membahas mengenai kinerja Bagian Pengaduan Masyarakat, Sekretariat Jenderal DPR RI dalam mengelola aspirasi dan pengaduan masyarakat.Peneliti menggunakan konsep-konsep mengenai organisasi birokrasi, dan kinerja. Penelitian ini menggunakan pendekatan kualitatif, tipe penelitian deskriptif dengan pengumpulan data melalui studi literatur, wawancara, dan pengamatan lapangan. Hasil penelitian menunjukkan bahwa Bagian Pengaduan Masyarakat memiliki permasalahan dalam hal kuantitas dan kualitas SDM di bagian analis. Bagian Pengaduan Masyarakat juga belum mampu mengelola pengaduan dan aspirasi masyarakat secara efektif dan efisien. Faktor ini berdampak pada kinerja Bagian Pengaduan Masyarakat belum maksimal. Selain itu, Bagian Pengaduan Masyarakat juga belum diberdayakan dengan baik oleh anggota DPR. Penelitian merekomendasikan bahwa perlu adanya pemenuhan kuantitas dan kualitas SDM oleh pihak Setjen dan pemberdayaan Bagian Pengaduan Masyarakat oleh pihak anggota DPR.
\end{abstract}

Kata kunci: pengaduan masyarakat, kinerja, organisasi, birokrasi

\section{Pendahuluan}

Di Indonesia dan hampir semua negara di dunia yang menjalankan demokrasi, kehadiran parlemen atau DPR begitu penting dan strategis sebagai representasi dari rakyat. Menurut Gaffar (2012: 61) anggota DPR merupakan salah satu hasil dari adanya dinamika pembaruan perjanjian sosial yang dilakukan melalui mekanisme pemilihan umum. Melalui mekanisme tersebut, rakyat memberikan mandat kepada wakil-wakil yang dipilihnya untuk melaksanakan kepentingan umum melalui fungsi yang melekat pada DPR, yaitu: legislasi, budgeting, dan pengawasan.

Di tangan para wakil rakyat berbagai kebijakan strategis yang menyangkut hajat hidup orang banyak dirumuskan. Oleh karena itu, sudah menjadi kewajiban bagi para wakil rakyat untuk bertindak sesuai dengan aspirasi masyarakat atau dalam bahasa Rousseau (1712-1778) disebut dengan kehendak umum (general will) (Ravicth \& Thernstrom, 1994: 102). Dalam kaitannya dengan partisipasi masyarakat tersebut, publik berhak untuk

Received: 10 Januari 2015, Revision: 25 Mei 2015, Accepted: 22 Juni 2015

Print ISSN: 0215-8175; Online ISSN: 2303-2499. Copyright@2015. Published by Pusat Penerbitan Universitas (P2U) LPPM Unisba Terakreditasi SK Kemendikbud, No.040/P/2014, berlaku 18-02-2014 s.d 18-02-2019 
menyampaikan aspirasi dan pengaduan kepada DPR sebagaimana telah diatur dalam UU No.No. 27 tahun 2009 jo UU No.17 tahun 2014 tentang MPR, DPR, DPD dan DPRD, pasal 72 huruf $(\mathrm{g})$ : "DPR mempunyai tugas untuk menyerap, menghimpun, menampung, dan menindaklanjuti aspirasi masyarakat." Selanjutnya, pada pasal 81 huruf (j) juga disebutkan bahwa kewajiban anggota DPR adalah menampung dan menindaklanjuti aspirasi dan pengaduan masyarakat.

Lebih lanjut, partisipasi masyarakat dipertegas dengan Peraturan DPR RI No. 01/ DPR RI/I/2009-2010 jo Peraturan DPR RI No.01 tahun 2014 tentang Tata Tertib DPR, pasal 7 huruf $(\mathrm{g})$, menyatakan bahwa DPR memunyai tugas dan wewenang untuk:

\begin{abstract}
"menyerap, menghimpun, menampung dan menindaklanjuti aspirasi masyarakat" dan pasal 12 huruf (j) menyatakan bahwa Anggota DPR mempunyai kewajiban "menampung dan menindaklanjuti aspirasi dan pengaduan masyarakat."
\end{abstract}

Untuk mengelola aspirasi dan pengaduan masyarakat ini, termasuk tugas anggota dewan lainnya, DPR secara keorganisasian memiliki sistem pendukung (supporting system), yaitu Sekretariat Jenderal (Setjen) Dewan Perwakilan Rakyat Republik Indonesia (DPR RI) sebagaimana diatur dalam UU No.27 tahun 2009 jo UU No.17 tahun 2014 tentang MPR, DPR, DPD dan DPRD. Setjen yang berkedudukan sebagai Kesekretariatan Lembaga Negara memberikan supporting dalam bentuk teknis, administratif, dan keahlian dalam rangka melaksanakan tugastugas anggota dewan.

Di DPR, aspirasi dan pengaduan masyarakat terbagi menjadi dua, yaitu secara langsung dan tidak langsung. Unit kerja yang menangani pengaduan dan aspirasi langsung di Setjen DPR adalah Bagian Hubungan Masyarakat (Humas) DPR. Sesuai dengan Pedoman Umum Pengelolaan Aspirasi dan Pengaduan Masyarakat, Bagian Humas menerima delegasi yang datang dan meneruskan kepada Alat Kelengkapan DPR (AKD) atau Fraksi yang ingin dituju. Sedangkan untuk pengaduan secara tidak langsung ditangani oleh Bagian Pengaduan Masyarakat yang berada di bawah Biro Pengawasan Legislatif.

Kehadiran Bagian Pengaduan Masyarakat menegaskan bahwa DPR membuka seluasluasnya partisipasi masyarakat. Dibukanya lebar-lebar pintu bagi masyarakat untuk berpartisipasi menyampaikan pengaduan dan aspirasi kepada DPR ternyata disambut antusiasme publik yang demikian besar. Hal ini tercermin dari banyaknya jumlah pengaduan dan aspirasi yang masuk ke DPR sebagaimana nampak dalam tabel di bawah ini:

Tabel 1

Pengaduan Masyarakat

Berdasarkan Jenis Medianya

\begin{tabular}{|c|c|c|c|c|}
\hline No. & $\begin{array}{c}\text { Jenis } \\
\text { Media }\end{array}$ & $\begin{array}{c}\text { Tahun } \\
\mathbf{2 0 1 1}\end{array}$ & $\begin{array}{c}\text { Tahun } \\
\mathbf{2 0 1 2}\end{array}$ & $\begin{array}{c}\text { Tahun } \\
\mathbf{2 0 1 3}\end{array}$ \\
\hline 1. & Surat & 3.448 & 4.993 & 4.160 \\
\hline 2. & Website & 595 & 688 & 906 \\
\hline 3. & SMS & 21.347 & 37.509 & 24.477 \\
\hline \multicolumn{2}{|r|}{ Jumlah } & 25.390 & 43.190 & 29.543 \\
\hline
\end{tabular}

Sumber: Bagian Pengaduan Masyarakat Sekretariat Jenderal DPR RI, 2014

Surat pengaduan dari masyarakat tersebut selanjutnya dikelompokkan ke dalam 12 bidang permasalahan, yaitu: politik/ hukum, tanah/rumah/bangunan, aparatur negara/kepegawaian, perburuhan/tenaga kerja, sosial/budaya, ekonomi dan keuangan, lingkungan hidup, kehutanan, pendidikan, agama, kesehatan, dan permasalahan lainnya. Untuk melihat data yang masuk terkait dengan pengaduan masyarakat sesuai dengan bidang permasalahan dapat dilihat dalam tabel berikut ini.

\section{Tabel 2}

Pengaduan Masyarakat Melalui Surat Per Bidang Permasalahan

\begin{tabular}{|c|l|c|c|}
\hline No. & \multicolumn{1}{|c|}{$\begin{array}{c}\text { Bidang } \\
\text { Permasalahan }\end{array}$} & $\begin{array}{c}\text { Tahun } \\
\mathbf{2 0 1 2}\end{array}$ & $\begin{array}{c}\text { Tahun } \\
\mathbf{2 0 1 3}\end{array}$ \\
\hline 1. & Politik/ hukum & 2.922 & 2.240 \\
\hline 2. & $\begin{array}{l}\text { Tanah/ rumah/ } \\
\text { bangunan }\end{array}$ & 764 & 599 \\
\hline 3. & $\begin{array}{l}\text { Aparatur negara/ } \\
\text { kepegawaian }\end{array}$ & 442 & 400 \\
\hline $\begin{array}{l}\text { 4. } \\
\text { Perburuhan/ tenaga kerja }\end{array}$ & 179 & 148 \\
\hline 5. & Sosial/ budaya & 148 & 117 \\
\hline 6. & $\begin{array}{l}\text { Ekonomi dan } \\
\text { keuangan }\end{array}$ & 123 & 233 \\
\hline 7. & Lingkungan hidup & 73 & 69 \\
\hline 8. & Kehutanan & 62 & 71 \\
\hline 9. & Pendidikan & 60 & 50 \\
\hline 10. & Agama & 44 & 38 \\
\hline 11. & Kesehatan & 16 & 17 \\
\hline 12. & $\begin{array}{l}\text { Permasalahan } \\
\text { lainnya }\end{array}$ & 4.993 & 4.160 \\
\hline \multicolumn{2}{|l|}{ Jumlah } & \\
\hline
\end{tabular}

Sumber: Bagian Pengaduan Masyarakat Sekretariat Jenderal DPR RI, 2014 
Selanjutnya, dalam rangka pelaksanaan supporting system untuk mengelola pengaduan dan aspirasi masyarakat tersebut, Bagian Pengaduan Masyarakat memiliki unitunit kerja. Unit kerja ini merupakan sebuah organisasi, yang menurut Davis (1951) dalam (Lubis \& Huseini, 2009:5) didefinisikan sebagai sekelompok orang atau individu yang saling berinteraksi menurut pola yang terstruktur dengan cara tertentu, di mana setiap orang memiliki tugas dan fungsinya masing-masing demi mencapai tujuan tertentu.

Kinerja yang optimal dari Bagian Pengaduan Masyarakat dalam mengelola pengaduan dan aspirasi sangat dibutuhkan dalam rangka menunjang tugas dewan untuk menyerap aspirasi dan pengaduan masyarakat. Untuk mewujudkan hal tersebut, Biro Pengawasan Legislatif selaku hierarki yang berada di atas Bagian Pengaduan Masyarakat menetapkan sasaran strategis organisasi. Adapun sasaran strategis yang terkait dengan Bagian Pengaduan Masyarakat adalah meningkatnya kualitas analisis pengaduan masyarakat yang disampaikan kepada DPR.

Guna mencapai sasaran strategis tersebut, dibuatlah indikator kinerja, yaitu presentase pengadministrasian dan analisis serta tindak lanjut surat pengaduan masyarakat yang ditujukan kepada DPR RI. Kemudian dalam rangka mencapai indikator kinerja tersebut, terdapat kegiatan-kegiatan yang harus dilakukan, seperti kegiatan rapatrapat, pencetakan dan penjilidan, kegiatan mengundang pakar, konsinyering, kunjungan kerja dalam negeri, dan kegiatan tim. Untuk lebih jelasnya dapat kita lihat dalam Tabel 3.

Potret kinerja Bagian pengaduan Masyarakat seharusnya tidak hanya sebatas pada presentase jumlah surat yang berhasil didistribusikan ke AKD seperti yang selama ini ada, tapi juga meliputi seluruh rangkaian dari mulai surat masuk, penyeleksian, analisa, distribusi, dan pengawalan terhadap tindak lanjut yang dilakukan oleh komisi/badan dan fraksi di DPR. Dengan begitu, Bagian Pengaduan Masyarakat benar-benar bisa menjadi jembatan antara masyarakat dengan DPR.

Hal ini penting dilakukan agar upaya untuk menangani pengaduan dan aspirasi masyarakat secara efektif dan efisien benarbenar terwujud. Selanjutnya, kondisi ideal tersebut akan tercermin dari terlaksananya pembahasan mengenai masalah yang diadukan dalam rapat-rapat di AKD dan adanya jawaban yang diberikan kepada pelapor atas aspirasi dan surat-surat pengaduan yang disampaikan ke DPR. Upaya mewujudkan kinerja yang optimal semakin menjadi niscaya karena organisasi publik selalu menjadi sorotan masyarakat. Hasil penelitian Bastaman (2010) dalam (Ariany\&Putra, 2013:33) menyebutkan bahwa kinerja organisasi publik masih minim, sehingga banyak masyarakat yang kecewa.

\section{Kajian Pustaka}

Menurut Schein (1970) dalam (McAuley, Duberley, \& Johnson, 2007: 12) organisasi didefiniskan sebagai koordinasi rasional dari kegiatan yang dilakukan sejumlah orang untuk pencapaian beberapa tujuan atau sasaran umum yang dinyatakan secara eksplisit,

Tabel 3

Capaian Kinerja Bagian Pengaduan Masyarakat Tahun Anggaran 2013

\begin{tabular}{|l|l|c|c|c|}
\hline \multicolumn{1}{|c|}{ Sasaran } & \multicolumn{1}{|c|}{ Indikator Kinerja } & Target & Realisasi & $\begin{array}{c}\text { Pencapaian } \\
\text { Kinerja }\end{array}$ \\
\hline $\begin{array}{l}\text { Meningkatnya kuali- } \\
\text { tas analisis pen- } \\
\text { gaduan masyarakat } \\
\text { yang disampaikan } \\
\text { kepada DPR RI. }\end{array}$ & $\begin{array}{l}\text { Presentase pengadministrasian dan } \\
\text { analisis serta tindak lanjut surat } \\
\text { pengaduan masyarakat yang ditujukan } \\
\text { kepada DPR }\end{array}$ & $100 \%$ & $\begin{array}{c}3.833 \text { dari } \\
4.160 \\
\text { surat }\end{array}$ & $92,1 \%$ \\
\cline { 2 - 5 } & a. Kegiatan rapat & 88 rapat & 56 rapat & $63,6 \%$ \\
\cline { 2 - 5 } & $\begin{array}{l}\text { b. Kegiatan pencetakan } \\
\text { dan penjilidan }\end{array}$ & 120 eks & (1 pintu) & - \\
\cline { 2 - 5 } & $\begin{array}{l}\text { c. Kegiatan diskusi } \\
\text { mengundang pakar }\end{array}$ & 8 diskusi & $45,45 \%$ \\
\cline { 2 - 5 } & d. Kegiatan konsinering & 4 kali & 11 kali & $137 \%$ \\
\cline { 2 - 5 } & e. Kunker dalam negeri & 8 kali & $125 \%$ \\
\cline { 2 - 5 } & f. Kegiatan tim & $100 \%$ \\
\hline
\end{tabular}


melalui pembagian tenaga kerja atau fungsi dan melalui hierarki kewenangan dan tanggung jawab.Pandangan ini menegaskan bahwa organisasi merupakan sebuah kerjasama diantara beberapa orang yang memiliki tujuan. Kemudian, untuk mewujudkan tujuan organisasi, diperlukan kiprah dari anggota organisasi, sebagaimana dikatakan oleh Gibson (1992) dalam (Rahminawati, AR, \& Umar, 2006:144):

"oranglah yang membuat organisasi berjalan,
dan orang juga yang berusaha mempengaruhi
orang lain dalam organisasi, yang akhirnya
menghasilkan karya keorganisasian yang
efektif".

Pandangan tersebut menegaskan bahwa kinerja organisasi sangat bergantung dari orang-orang yang ada dalam organisasi. Hal ini juga selaras dengan apa yang pernah disampaikan oleh Rate dan Stenberg dalam (Fox, Cooper, \& Klimoski, 2007: 4)

"When good people do nothing, institutions
(government, private, non-profit) experience
serious consequences. When entire groups
of good people collude to overlook, deny, or
manage around the negative actions of their
fellow employees, senior executives and others,
they demonstrate a failure of courage"

Selain itu, organisasi menurut Supardi dan Anwar (2004: 6-18) juga memiliki beberapa asas, yaitu: perumusan tujuan, departementasi, pembagian kerja, delegasi kekuasaan, kesatuan komando, koordinasi, rentangan kontrol, Asas jenjang organisasi, fleksibilitas, berkelangsungan, dan keseimbangan.

Bagian Pengaduan Masyarakat merupakan bentuk dari organisasi birokrasi. Ciri birokrasi menurut Weber adalah kekuasaan terdapat pada setiap hierarki jabatan pejabat, semakin tinggi hierarki jabatan maka semakin besar kekuasaannya dan semakin rendah hierarkinya maka akan semakin kecil pula kekuasaannya (powerless) (Thoha, 2012: 7).

Weber berpandangan bahwa birokrasi merupakan tahapan puncak dari perkembangan sistem administrasi yang rasional.Birokrasi dinilai rasional karena memiliki kendali berdasarkan keahlian teknis dan sesuai dengan aturan-aturan yang telah ditetapkan (Tompkins, 2005: 43).

Selanjutnya, mendukung pandangan Weber, Rourke (1978) dalam (Said, 2009: 2) menyatakan bahwa birokrasi merupakan sebuah sistem administrasi dan pelaksanaan tugas keseharian yang terstruktur, dalam sistem hierarki yang jelas, dilakukan dengan aturan tertulis (written procedures), dilakukan oleh bagian tertentu yang terpisah dengan bagian lainnya, oleh orang yang dipilih karena kemampuan dan keahlian dibidangnya.

Birokrasi sebagaimana dikemukakan oleh Weber dan Rourke memang mengandung unsur profesionalitas di mana jabatan-jabatan berdasarkan keahlian tertentu. Prosedur dan rantai hierarki dalam birokrasi juga jelas dan mengedepankan formalitas.Sepintas tidak ada yang salah dengan konsep tersebut, namun dalam perkembangannya birokrasi justru menciptakan kesulitan tersendiri dalam upaya melayani masyarakat.Birokrasi justru mendapat stigma negatif dari masyarakat. Meskipun memiliki spirit untuk efisiensi administratif, namun birokrasi justru berlaku sebaliknya. Pengaturan-pengaturan yang resminya diberlakukan untuk memperbaiki efisiensi kerap menimbulkan ekses yang malah jadi penghalang (Blau \& Meyer, 1987: 83).

Bagian Pengaduan Masyarakat sebagai sebuah birokrasi tentu tidak luput dari permasalahan keorganisasian sebagaimana telah disebutkan di atas. Meskipun begitu, Bagian Pengaduan Masyarakat dituntut untuk memiliki kinerja yang maksimal. Menurut Prawiro Suntoro (1999) dalam (Tika, 2008:121), kinerja didefinisikan sebagai hasil kerja yang dapat dicapai seseorang atau sekelompok orang dalam suatu organisasi dalam rangka mencapai tujuan organisasi dalam periode waktu tertentu.

Poister (2003: 12) merumuskan manajemen kinerja sebagai

Process of directing and controlling employees
and work units in an organization and motivating
them to perform at higher levels. Providing
feedback to employees on their performance
is a central element of effective approaches to
performance management.

Namun, sasaran dan indikator yang dibuat tidak serta-merta membuat sebuah organisasi mampu memiliki kinerja yang optimal.Menurut Ruky (2001) dalam (Tangkilisan, 2007: 180-181) tingkat pencapaian kinerja dipengaruhi oleh beberapa faktor.

Pertama, teknologi. Hal ini meliputi peralatan kerja dan metode kerja yang digunakan untuk menghasilkan produk atau jasa yang dihasilkan oleh organisasi. Semakin berkualitas teknologi yang digunakan, maka akan semakin tinggi tingkat kinerja organisasi tersebut. Kedua, kualitas input atau material yang digunakan oleh organisasi. Semakin baik dalam memilih sumber-sumber yang menjadi 
masukan bagi organisasi akan membantu organisasi bekerja secara maksimal. Ketiga, kualitas lingkungan fisik yang meliputi keselamatan kerja, penataan ruang, dan kebersihan. Meski terlihat sederhana, namun hal ini penting dalam rangka menciptakan suasana kerja yang nyaman dan aman agar organisasi bisa lebih produktif. Keempat, Budaya organisasi sebagai pola tingkah laku dan pola kerja yang ada dalam organisasi yang bersangkutan. Organisasi yang memiliki kultur baik, seperti kekeluargaan, dan selalu ingin menjadi yang terdepan tentu akan memiliki kinerja yang baik pula. Kelima, aspek kepemimpinan. Hal ini dibutuhkan untuk mengendalikan anggota organisasi agar bekerja sesuai dengan standar dan tujuan organisasi. Keenam, pengelolaan sumber daya manusia. Hal ini meliputi aspek kompensasi, imbalan, promosi, dan lainlainnya.Para anggota organisasi tentunya ingin setiap kerjanya dihargai, baik dalam bentuk materil maupun immateril.

Pendekatan yang digunakan dalam penelitian ini adalah pendekatan kualitatif, karena peneliti ingin mendapatkan gambaran yang lebih mendalam mengenai kinerja Bagian Pengaduan Masyarakat Sekretariat Jenderal DPR RI dalam mengelola aspirasi dan pengaduan masyarakat. Pendekatan kualitatif juga dipilih lantaran fokus kajian ini bukan dalam rangka mengukur kinerja Bagian Pengaduan Masyarakat, melainkan sekadar mendeskripsikan fenomena terkait dengan kinerja dalam melakukan pengelolaan aspirasi dan pengaduan masyarakat yang ditemui selama penelitian ini dilakukan, baik melalui observasi, wawancara, maupun penelusuran dokumen. Adapun data kuantitatif yang muncul dalam penelitian ini merupakan data sekunder yang didapat dari Sekretariat Jenderal DPR RI dan sejumlah dokumen lainnya.

Penelitian ini menggunakan beberapa teknik pengumpulan data. Studi pustaka dilakukan dengan menelusuri buku-buku, jurnal, tesis, disertasi, koran, internet, dan serangkaian peraturan-peraturan, serta dokumen terkait lainnya. Selain itu, peneliti juga melakukan observasi lapangan dalam ranga mendapatkan gambaran yang lebih detil mengenai objek yang sedang dikaji.Kemudian, wawancara mendalam juga dilakukan untuk mendapatkan data-data kualitatif dari para pihak yang terkait dalam proses pengelolaan aspirasi dan pengaduan masyarakat di DPR. Para informan adalah orang yang berkepentingan dengan pengelolaan aspirasi dan pengaduan masyarakat di DPR, seperti Kepala Biro Pengawasan Legislatif, Kepala Bagian Pengaduan Masyarakat, Pimpinan Alat Kelengkapan DPR (2009-2014), Kepala Sekretariat Komisi, dan pihak pengadu atau pelapor.

\section{Alur Pengelolaan Aspirasi dan Pengaduan Masyarakat}

Sebagai sebuah organisasi, Bagian Pengaduan Masyarakat Sekretariat Jenderal DPR RI merupakan birokrasi yang hidup di lembaga politik. Bahkan, secara khusus, Bagian Pengaduan Masyarakat bekerja untuk melayani para politisi dalam rangka menjembatani kepentingan rakyat dengan wakil-wakilnya di DPR. Meskipun begitu, pada praktiknya, pengaduan dan aspirasi masyarakat yang dikelola oleh Sekretariat Jenderal DPR sangat birokratis, sehingga menghambat proses penyampaian aspirasi dan pengaduan masyarakat ke DPR.

Misalnya, semua surat aspirasi dan pengaduan yang masuk harus mendapatkan disposisi dari pimpinan, baik sebelum dianalisis maupun sebelum dikirimkan ke pimpinan DPR ataupun pimpinan AKD. Ketika sampai di AKD, surat juga harus melalui disposisi sebelum ditangani. Artinya, penanganan surat harus melewati rantai birokrasi yang panjang.

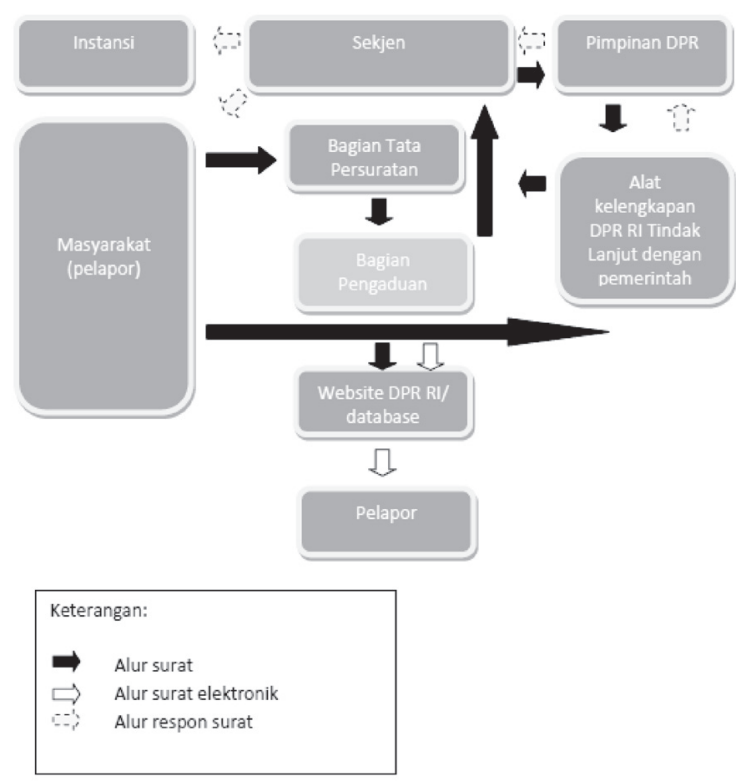

Sumber: Buku Pedoman Umum Pengelolaan Aspirasi dan Pengaduan Masyarakat, 2010

Gambar 1. Alur Pengelolaan Aspirasi dan Pengaduan Masyarakat Melalui Surat

Tata kelola aspirasi dan pengaduan masyarakat yang masuk ke DPR, baik melalui 
surat, email, SMS, dan hotline merupakan bentuk mekanisme kerja yang mengatur bagaimana Sekretariat Jenderal, khususnya Bagian Pengaduan Masyarakat menangani pengaduan dan aspirasi masyarakat sejak masuk, hingga kemudian ditindaklanjuti oleh dewan. Hal ini tidak hanya terkait dengan proses tapi juga hubungan kerja antar bagianbagian yang ada dalam lingkup Kesetjenan DPR RI.

Masing-masing bagian, baik itu Bagian Pengaduan Masyarakat, Unsur AKD yang meliputi Sekretariat AKD dan Pimpinan AKD, termasuk anggota-anggotanya memiliki tugas, tanggung jawab, dan kewenangan masing-masing yang diatur melalui undangundang, peraturan Sekretariat Jenderal, dan Pedoman Pengelolaan Aspirasi dan Pengaduan masyarakat yang dikeluarkan oleh BURT.

Dalam kaitannya dengan hal tersebut, aspirasi dan pengaduan masyarakat di DPR dikelola oleh Sekretariat Jenderal melalui Bagian Pengaduan Masyarakat pada prinsipnya memenuhi asas-asas yang dimiliki oleh organisasi, seperti adanya tujuan yang hendak dicapai, departementasi, pembagian kerja, delegasi kekuasaan, kesatuan komando, koordinasi, rentang kendali, dan adanya jenjang organisasi.

Kemudian, dalam menyukseskan pengelolaan aspirasi dan pengaduan tersebut, juga terdapat instrumen untuk melakukan kontrol agar proses tersebut berjalan sebagaimana mestinya dan mampu memenuhi tujuan organisasi, yaitu: adanya otoritas, penggunaan perintah, peraturan, dan anggaran untuk membiayai upaya pencapaian tujuan. Lebih lanjut, tata kelola dalam pengelolaan aspirasi dan pengaduan masyarakat tersebut juga menunjukkan bagaimana sebuah birokrasi bekerja. Hal tersebut dicirikan dengan adanya tugastugas dibagi sesuai dengan fungsinya. Tugas Bagian Pengaduan Masyarakat dengan Sekretariat AKD berbeda. AKD merupakan pintu akhir yang akan menindaklanjuti aspirasi dan pengaduan masyarakat yang telah dikelola secara administratif dan teknis oleh Bagian Pengaduan Masyarakat. Aturan yang dibuat juga disesuaikan dengan pekerjaannya, yang diwujudkan dalam bentuk SOP, Pedoman Pengelolaan, dan Peraturan Sekjen. Administrasi dalam pengelolaan tersebut juga dilakukan dengan menggunakan dokumen tertulis, seperti adanya pembuatan nota dinas untuk disposisi surat-surat yang telah selesai dilakukan analisis dan akan dikirimkan ke otoritas yang lebih tinggi dan bagian lain dalam rantai pengelolaan aspirasi dan pengaduan masyarakat.

\section{Aspek Sumber Daya Manusia}

Terkait dengan kinerja, Keterbatasan SDM (hanya empat orang analis) membuat proses pengelolaan aspirasi dan pengaduan masyarakat berjalan lambat. Volume surat yang banyak dan berasal dari berbagai media (surat, email, dan SMS) tentu membuat aspirasi dan pengaduan masyarakat tidak bisa langsung ditangani, sehingga secara otomatis akan banyak yang terpending.

Penyebab terpendingnya surat-surat yang masuk menjadi semakin banyak lantaran para analis di Bagian Pengaduan Masyarakat tidak bekerja berdasarkan target penyelesaian surat per hari. Hal ini sebagai akibat mereka tidak hanya menangani analisis saja tapi juga laporan-laporan lainnya dan persiapan ketika hendak mengadakan diskusi ataupun kunjungan kerja. Untuk menyiasati hal tersebut, strategi yang dipakai adalah bukan pada target penyelesaian per hari, melainkan target tahunan dan per masa sidang, yakni berapa jumlah total surat masuk dalam setahun masa sidang dan berapa surat yang berhasil didistribusikan ke pimpinan dan alat kelengkapan DPR.

Selain terkait dengan waktu, proses penanganan aspirasi dan pengaduan berdasarkan hasil akhir juga akan berdampak pada kualitas analisis yang dilakukan oleh para analis. Waktu yang semakin sempit dengan keterbatasan SDM tentunya akan berpengaruh dalam analisis yang diberikan. Terutama menyangkut pencarian dasar hukum yang sesuai dengan permasalahan yang diadukan oleh pelapor.

Masalah ini kemudian diperparah dengan kondisi SDM yang tidak memenuhi standar. Hal ini terjadi karena pihak Setjen kurang memperhatikan pemenuhan SDM di Bagian Pengaduan Masyarakat. Banyak pegawai yang tidak memenuhi kualifikasi ditempatkan di Bagian Pengaduan Masyarakat. Padahal seorang analis harus memiliki kualifikasi yang tepat agar mampu menganalisis suratsurat yang masuk dengan baik (Wawancara dengan Endang Suryastuti, 21 Oktober 2014). Bagian Pengaduan Masyarakat menghendaki para analis memiliki kualifikasi pendidikan sarjana hukum guna menunjang kinerja dalam menganalisa surat. Hal ini dikarenakan analisis yang dilakukan di Bagian Pengaduan Masyarakat lebih bersifat normatif, yaitu 
terkait dengan aturan perundang-undangan.

Saat ini, dari dua Kasubag yang ada di Bagian Pengaduan Masyarakat, hanya satu orang yang memiliki kualifikasi pendidikan sarjana hukum. Kemudian, dari empat orang analis, hanya satu orang yang berpendidikan sarjana hukum. Terkait dengan persoalan persoalan ini, pada praktiknya tidak dapat ditangani sendiri oleh Bagian Pengaduan Masyarakat. Namun, masalah tersebut tergantung dengan bagian lain dalam organisasi Kesetjenan, seperti Biro Kepegawaian.

Kepala Bagian Pengaduan Masyarakat dan Kepala Biro Pengawasan Legislatif sudah mengajukan usul penambahan pegawai. Namun tetap saja hingga saat ini masih belum ada penambahan. Sehingga, karena keterbatasan tersebut, Bagian Pengaduan Masyarakat masih belum bisa menangani seluruh aspirasi dan pengaduan masyarakat yang masuk.

Selanjutnya, meski kualitas analisis rendah, namun pelatihan untuk meningkatkan kapasitas mereka masih minim. Kegiatan mengundang pakar yang selama ini dilakukan lebih kepada mendapatkan masukan mengenai permasalahan-permasalahan khusus yang memang membutuhkan perspektif dari pakar, misal ahli hukum, ahli pertahanan, dan kepegawaian.

\section{Aspek Birokrasi dalam Organisasi}

Selain dari aspek SDM, struktur organisasi ikut mempengaruhi kinerja Bagian Pengaduan Masyarakat. Struktur tersebut didukung dengan mekanisme birokrasi dalam menangani surat-surat aspirasi dan pengaduan masyarakat membuat pelayanan tidak optimal. Serangkaian pengaturan inilah yang kemudian justru menghalangi terciptanya efektifitas dan efisiensi pengelolaan aspirasi dan pengaduan masyarakat.

Surat-surat yang masuk ke Bagian Pengaduan Masyarakat melalui Bagian Tata Persuratan didisposisikan oleh Kepala Bagian Pengaduan Masyarakat ke Kasubag Analisa. Dari Kasubag Analisa tersebut, surat kemudian didistribusikan kepada masing-masing analis. Setelah surat selesai dianalisis kemudian diperiksa oleh Kasubag Analisa untuk selanjutnya dibuatkan nota dinas untuk disampaikan kepada Kepala Bagian Pengaduan Masyarakat. Kepala Bagian Pengaduan Masyarakat kemudian mengoreksi kembali hasil analisa. Setelah dikoreksi, surat kemudian diperbaiki oleh analis dan selanjutnya Kepala Bagian Pengaduan Masyarakat menugaskan Kasubag Administrasi Pengawasan dan Legislatif

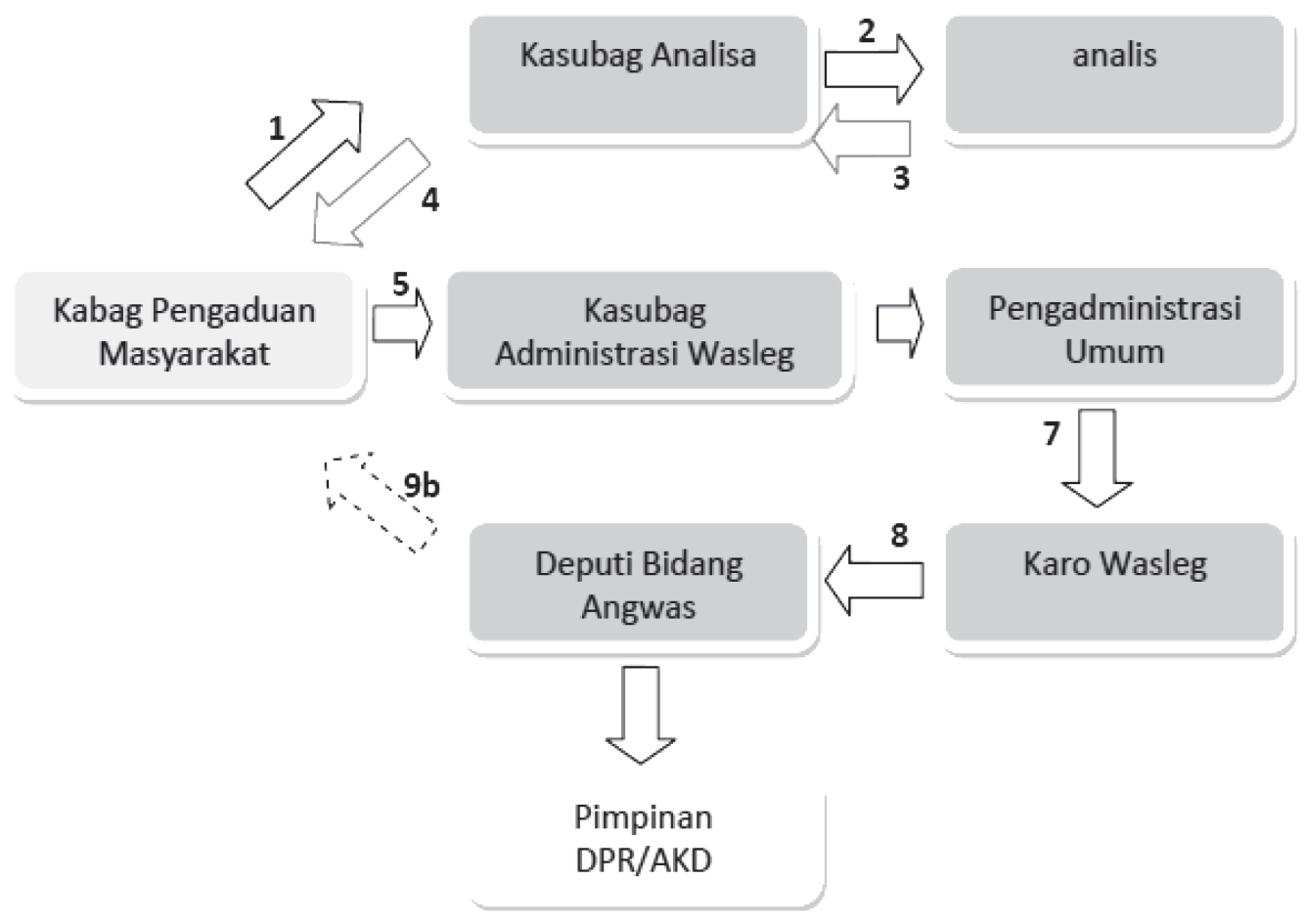

Gambar 2

Proses Pengelolaan Aspirasi dan Pengaduan Masyarakat di Bagian Pengaduan Masyarakat 
untuk membuat nota dinas penyampaian analisa kepada Kepala Biro Pengawasan dan Legislatif. Setelah itu, surat kemudian disampaikan kepada Deputi Bidang Anggaran dan Pengawasan. Setelah dikoreksi dan diparaf, surat kemudian disampaikan kepada pimpinan DPR atau AKD. Salinan dari surat tersebut kemudian dikembalikan ke Kepala Bagian Pengaduan Masyarakat untuk selanjutnya diarsip.

Hal inilah yang kemudian dikeluhkan oleh masyarakat atau pihak pelapor mengenai lambatnya tindak-lanjut surat yang telah dikirimkan ke DPR. Menurut pengakuan Edhi Martono (Wawancara, 1 Desember 2014) yang pernah mengadukan permasalahannya ke DPR, balasan atau respon dari surat yang dikirimkan ke DPR melalui email dan pos baru diterimanya setelah menunggu selama empat bulan. Hal senada juga dialami oleh Istiqomah saat mengadukan permasalahan perijinan untuk membeli cangkang atau kulit kerang sebagai bahan baku kerajinan. Bahkan surat yang dikirimkan oleh Istiqomah dan suaminya baru ada kabar setelah yang bersangkutan bertandang ke DPR untuk menanyakan kelanjutan surat tersebut (Wawancara, 30 Nopember 2014).

Tak hanya pengadu saja yang merasakan lambatnya proses yang dilakukan oleh Bagian Pengaduan Masyarakat. Kepala Bagian Sekretariat Komisi III DPR RI, Tri Utami (Wawancara, 19 Nopember 2014) juga merasakan hal serupa. Menurutnya, mulai dari surat masuk hingga kemudian dianalisis dan dikirimkan ke komisi-komisi cukup lama.

\section{Aspek Kepemimpinan}

Dari aspek kepemimpinan, meskipun Kepala Bagian Pengaduan Masyarakat saat ini mampu membawa perubahan dalam penanganan aspirasi dan pengaduan masyarakat. Namun masih ada beberapa hal yang menjadi catatan. Misalnya, Kepala Bagian Pengaduan Masyarakat masih belum menjalankan Standard Operating Procedure (SOP) dengan tegas agar proses pengelolaan aspirasi dan pengaduan masyarakat berjalan efektif dan efisien. Hal ini nampak dengan adanya dispensasi terkait dengan ketepatan waktu dalam menangani aspirasi dan pengaduan masyarakat. Selain karena persoalan SDM, adaptasi dengan kultur organisasi juga menjadi pertimbangan.

Padahal, menurut aturan, semua surat harus dianalisa oleh Bagian Pengaduan Masyarakat. Namun sudah sejak lama Bagian
Pengaduan Masyarakat hanya menganalisa surat yang ditujukan ke Pimpinan DPR, sedangkan untuk surat yang ditujukan ke AKD tidak dilakukan analisa dan hanya dibuatkan kronologis saja. Hal ini dikarenakan keterbatasan SDM dan tingginya volume surat yang masuk ke DPR. Seharusnya, karena Bagian Pengaduan Masyarakat merupakan penanggungjawab utama aspirasi dan pengaduan masyarakat melalui surat-surat, maka wajib melakukan analisa.

\section{Aspek Anggota Dewan}

Dalam pengelolaan aspirasi dan pengaduan masyarakat di DPR RI, kehadiran Bagian Pengaduan Masyarakat sejatinya sangat dibutuhkan. Namun, baik Sekretariat Jenderal maupun anggota DPR masih belum memaksimalkan fungsi supporting yang dijalankan oleh Bagian Pengaduan Masyarakat.

Keluhan yang kerap disampaikan oleh Bagian Pengaduan Masyarakat adalah mengenai kemauan (willingness) dari anggota DPR, khususnya pimpinan-pimpinan di AKD untuk menindaklanjuti aspirasi dan pengaduan masyarakat. Hal inilah yang seringkali membuat aspirasi dan pengaduan masyarakat tidak tuntas.

Menurut pengakuan Kepala Bagian Pengaduan Masyarakat, Endang Suryastuti (Wawancara, 21 Oktober 2014), anggota DPR lebih dominan menjalankan fungsi legislasi dan budgeting daripada pengawasan. Kemudian, tugas-tugas kedewanan juga sangat banyak, sehingga tidak sempat mengagendakan waktu untuk membahas pengaduan dari masyarakat. $\mathrm{Hal}$ ini menyebabkan penanganan pengaduan masyarakat kerap terbengkalai. Kepala Subbagian Tata Usaha Komisi X bahkan secara terang-terangan mengatakan ditindaklanjuti atau tidaknya aspirasi dan pengaduan masyarakat sangat tergantung dari anggota DPR, karena merekalah yang memiliki kewenangan untuk memutuskan (Wawancara dengan Ahmad Mufarod, 24 Nopember 2014). Selain itu, kepentingan masing-masing anggota DPR juga ikut memengaruhi respon dewan dalam penanganan aspirasi dan pengaduan masyarakat. Bila permasalahan yang diadukan terkait dengan isu nasional atau menyangkut masyarakat banyak, seperti kasus Mesuji di Lampung, maka respon anggota DPR akan sangat cepat. Namun, bila permasalahan sifatnya personal dan tidak berdampak luas, anggota dewan umumnya kurang memberikan perhatian.

$$
\text { Selanjutnya, bila pelapor atau }
$$


permasalahan yang diadukan menyangkut daerah pemilihannya, anggota DPR juga akan sigap menanganinya. Sebagian besar anggota DPR sangat menaruh perhatian yang lebih terhadap isu-isu yang berkembang di daerah pemilihannya. Kemudian, penanganan pengaduan dan aspirasi yang masuk melalui anggota DPR langsung dan melalui ke Sekretariat Jenderal juga berbeda.

Pengaduan yang disampaikan langsung kepada anggota DPR biasanya akan cepat ditindaklanjuti dari yang disampaikan melalui Bagian Pengaduan Masyarakat. Karena, pengaduan yang disampaikan secara langsung ke anggota DPR bisa langsung segera dimintakan kepada pimpinan agar diagendakan dalam rapat dengar pendapat atau langsung disampaikan kepada mitra kerja oleh anggota dewan yang bersangkutan tanpa melalui alur birokrasi yang panjang.

\section{Aspek Teknologi}

Selanjutnya, terkait dengan penggunaan teknologi dalam pengelolaan aspirasi dan pengaduan masyarakat masih belum dimaksimalkan. Proses penggunaan sistem IT pengaduan hanya dijalankan di Bagian Pengaduan Masyarakat saja. Padahal, pengelolaan pengaduan dan aspirasi merupakan sebuah kesatuan sistem yang terintegrasi mulai dari Bagian Pengaduan Masyarakat hingga alat kelengkapan DPR.

Bila sistem IT mengenai pengelolaan aspirasi dan pengaduan masyarakat ini bisa dimaksimalkan, tentu rantai birokrasi yang panjang bisa diminimalisasi, sehingga pengelolaan pengaduan dan aspirasi menjadi maksimal. Selain itu, selama ini anggota dewan selaku pengguna dari layanan pengelolaan aspirasi dan pengaduan yang disediakan oleh Sekretariat Jenderal juga tidak bisa mengakses informasi yang tersedia di sistem pengelolaan aspirasi dan pengaduan masyarakat, kecuali melalui staf di bagian alat kelengkapan DPR.

Hal ini tentunya membuat proses diterimanya pengaduan dan aspirasi masyarakat oleh anggota dewan menjadi lambat. Bila saja anggota DPR memiliki akun atau username yang bisa dipakai untuk masuk ke dalam sistem pengelolaan aspirasi dan pengaduan masyarakat, pasti bisa membuat aspirasi dan pengaduan tersalurkan dengan cepat.

Bahkan, secara real-time anggota DPR dapat memantau aspirasi dan pengaduan masyarakat yang masuk, baik berdasarkan bidang komisinya maupun berdasarkan daerah pemilihannya. Dalam hal ini, staf anggota DPR seperti asisten pribadi dan tenaga ahli juga dapat ditugaskan untuk memilah dan menyarikan aspirasi dan pengaduan masyarakat sebagai bahan rapat dan kunjungan kerja.

Secara umum, kenapa supporting yang dilakukan oleh Bagian Pengaduan Masyarakat dalam mengelola aspirasi dan pengaduan masyarakat belum dimaksimalkan oleh anggota dewan, antara lain menyangkut beberapa hal. Pertama, kurangnya pengetahuan anggota DPR mengenai adanya Bagian Pengaduan Masyarakat di DPR yang bertugas mengelola aspirasi dan pengaduan masyarakat. Bahkan, tidak semua level pimpinan AKD mengetahui adanya sebuah unit di Sekretariat Jenderal yang betugas mengelola aspirasi dan pengaduan masyarakat.

Kedua, tidak semua anggota dewan mau menangani pengaduan masyarakat. Tidak banyak wakil rakyat yang benar-benar mau mengurusi aspirasi dan pengaduan masyarakat. Hal ini juga diakui oleh anggota DPR dari Fraksi PDI Perjuangan, Ribka Tjiptaning (Wawancara, 1 desember 2014). Menurutnya, masih banyak anggota DPR yang hanya mau rapat dengan menteri saja, tapi bila rapat-rapat untuk mendengarkan aspirasi dan pengaduan masyarakat tidak mau.

Ketiga, kurangnya pemanfaatan hasil kerja Bagian Pengaduan Masyarakat adalah karena banyaknya mekanisme aspirasi dan pengaduan masyarakat yang bisa dihimpun oleh anggota DPR, mulai dari kunjungan kerja, berita di media massa, email pribadi, SMS langsung, website pribadi, surat yang dikirimkan langsung ke anggota dewan, hingga diskusi dengan pakar yang ditemui dalam berbagai kesempatan.

\section{Simpulan dan Saran}

Berdasarkan uraian pembahasan di atas, dapat disimpulkan bahwa kinerja Bagian Pengaduan Masyarakat belum maksimal. Hal ini secara otomatis berpengaruh dalam usaha mendukung tugas-tugas dewan dalam menyerap aspirasi dan pengaduan masyarakat. Ada beberapa hal yang menyebabkan kinerja Bagian Pengaduan Masyarakat belum maksimal.

Pertama, kuantitas dan kualitas SDM belum memenuhi standar. Jumlah SDM masih minim dan pelatihan dalam rangka 
meningkatkan kualitasjuga belum dilaksanakan dengan baik. Kedua, Bagian Pengaduan Masyarakat masih belum menjalankan aturan sepenuhnya. Meskipun seharusnya semua surat yang masuk dianalisis, namun pada praktiknya hanya surat-surat yang ditujukan ke pimpinan saja yang dilakukan analisis. Bagian Pengaduan Masyarakat juga tidak melakukan analisis. Ketiga, Sekretariat Jenderal belum memberikan perhatian guna penguatan terhadap Bagian Pengaduan Masyarakat. Meskipun permintaan mengenai penambahan SDM sudah dilakukan tapi belum dipenuhi.

Selain itu, selama ini kehadiran Bagian Pengaduan Masyarakat masih belum diberdayakan dengan baik oleh anggota DPR. Ada beberapa hal yang menyebabkan itu terjadi. Pertama, tidak semua anggota mengetahui adanya Bagian Pengaduan Masyarakat. Anggota DPR umumnya hanya mengetahui aspirasi dan pengaduan yang datang melalui Fraksi dan Komisi. Kedua, tidak semua anggota dewan mau menangani pengaduan masyarakat. Ketiga, banyaknya cara yang bisa dilakukan oleh anggota dewan untuk mendapatkan aspirasi dan pengaduan masyarakat selain dari Bagian Pengaduan Masyarakat DPR RI, sehingga Bagian Pengaduan Masyarakat kurang dilirik.

Terkait dengan simpulan tersebut, penulis merekomendasikan beberapa hal guna meningkatkan kinerja Bagian Pengaduan Masyarakat. Pihak Sekretariat Jenderal harus lebih memperhatikan dan memberikan dukungan yang maksimal kepada Bagian Pengaduan Masyarakat, seperti dengan meningkatkan kuantitas dan kualitas SDMnya. Kemudian, perlu adanya pemangkasan alur proses penanganan surat-surat agar menjadi lebih cepat. Selanjutnya, sebagai wakil rakyat, anggota DPR harus mau menindaklanjuti aspirasi dan pengaduan masyarakat, dengan kata lain anggota DPR harus lebih memberdayakan Bagian Pengaduan Masyarakat untuk menyerap aspirasi dan pengaduan masyarakat.

\section{Daftar Pustaka}

Ariany, Ria.,\& Putera Roni Ekha. (2013). Analisis Kinerja Organisasi Pemerintah dalam Memberikan Pelayanan Publik di Kota Pariaman. Jurnal Mimbar, LPPM Unisba, Vol. 29, No.1 (Juni), pp: 33-40
Blau, Peter M., \& Meyer, Marshal W. (1987). Birokrasi dalam Masyarakat Modern (2nd ed) (Gary R. Jusuf: penerjemah). Jakarta: UI Press.

Fahmi, Irham. (2010), Manajemen Kinerja: Teori dan Aplikasi. Bandung:

Alfabeta.

Fox, Janice Langan., \& Cooper CBE, Cary L., \& Klimoski, Richard J. (2007). Research Companion to the Dysfunctional Workplace ManagementChallenges and Symptoms. Cheltenham: Edward Elgar Publishing Limited.

Gaffar, Janedjri M. (2012). Demokrasi Konstitusional: Politik Ketatanegraan Indonesia Setelah Perubahan UUD 1945 (Cet.1). Jakarta: Konstitusi Press.

Lubis, Hari S.B \& Huseini, Martani. (2009). Pengantar Teori Organisasi: Suatu Pendekatan Makro. Jakarta: Departemen IImu Administrasi FISIP UI.

McAuley, John.,\& Duberley, Joanne., \& Johnson, Phil. (2007). Organization Theory: Challenges and Perspectives. Harlow: Pearson Education Limited.

Poister, Theodore H. (2003). Measuring performance in public and nonprofit organizations. San Fransisco: John Wiley \& Sons, Inc.

Rahminawati, Nan.,\& AR, Hendarsyah N.,\& Umar Muthia. (2006), Kemampuan Manajerial Pengurus Organisasi Dalam Upaya Meningkatkan Kinerja Organisasi Islam Perempuan di Jawa Barat, Jurnal Mimbar Unisba, Vol.22, No.2 (April-Juni), pp 143-164.

Ravitch, Diane \& Thernstrom, Abigail (Ed.).(1994). Demokrasi Klasik dan Modern (Cet.1) (Hermoyo, Penerjemah). Jakarta: Yayasan Obor Indonesia.

Said, M. Mas'ud. (2009). Birorkasi di Negara Demokratis: Makna, masalah, dan Dekonstruksi Birokrasi di Indonesia. Malang: UMM Press.

Supardi, Anwar Syaiful. (2004). Dasar-Dasar Perilaku Organisasi (Cet.2). Yogyakarta: UII Press.

Tangkilisan, Hessel Nogi S. (2007).Manajemen Publik (Cet.2). Jakarta: PT Grasindo.

Tika, Moh Pabundu. (2008). Budaya Organisasi dan peningkatan Kinerja Perusahaan (Cet.2). Jakarta: PT Bumi Aksara.

Thoha, Miftah. (2012). Birokrasi dan Politik di Indonesia (Cet.9). Jakarta: PT Raja Grafindo Persada.

Tompkins, Jonathan R. (2005). Organization Theory and Public Management. Boston: Wadsworth Cengage learning. 